\title{
Leadership Of Global Carbon Market
}

\author{
M. Anaam Hashmi, Minnesota State University, USA
}

\begin{abstract}
Carbon credits trading and the need to reduce carbon emissions are slowly being accepted as new realities of global business. A number of institutions played crucial role in developing the global carbon market. The World Bank Group, the World Resource Institute, the Institutional Investor's Group on Climate Change, and the Carbon Disclosure Project are some of the pioneers in developing the global carbon industry. The United States government did not assume the leadership role of the global carbon market as expected by world governments and corporations. The purpose of this study is to analyze the United States government's position vis-à-vis the global carbon market and explore the leadership role played by other global institutions.
\end{abstract}

\section{INTRODUCTION}

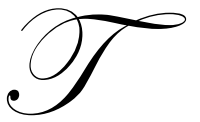

he carbon market provides a market-based mechanism for solving global environmental problem. This mechanism offers financial rewards to the corporations and countries taking steps to cut their greenhouse gas (GHG) emissions. At the same time, there is a cost to corporations and countries if they continue their business-as-usual policies regarding GHG emissions. The six main greenhouse gases are carbon dioxide $(\mathrm{CO} 2)$, methane $(\mathrm{CH} 4)$, nitrous oxide $(\mathrm{N} 2 \mathrm{O})$, hydrofluorocarbons (HFCs), perfluorocarbons (PFCs), and sulfur hexafluoride (SF6).

Carbon credits trading and the need to reduce carbon emissions are slowly being accepted as new realities of global business. A number of institutions played crucial role in developing the global carbon market. The World Bank Group, the World Resource Institute, the Institutional Investor's Group on Climate Change, and the Carbon Disclosure Project are some of the pioneers in developing the global carbon industry. The United States government did not assume the leadership role of the global carbon market as expected by world governments and corporations. The purpose of this study is to analyze the United States government's position vis-à-vis the global carbon market and explore the leadership role played by other global institutions.

\section{THE ROLE OF THE UNITED STATES OF AMERICA}

The United States has criticized the Kyoto Protocol as unfair because it does not impose any GHG emissions reduction quotas on China and other polluting countries. The United States, however, has pledged to reduce its "carbon intensity" by 18 percent before 2012. Carbon intensity is the ratio of carbon emissions to economic activity, so it is a measure of economic efficiency and not a measure of actual CO2e reduction. That is why the United States may still have a higher CO2e emissions level by 2012, despite a reduction of carbon intensity (Eilperin 2005). The Bush administration's position is that the Kyoto Protocol will slow down economic growth and may cause job loss in the United States. Opponents of the Kyoto Protocol assert the cost of implementing this agreement outweigh the benefits because mandatory reduction of GHG emissions will increase the cost of production in many industries and eventually hamper economic growth. The Bush administration estimated that the Kyoto Protocol's mandates will cost $\$ 400$ billion to the United States' economy (The Wall Street Journal 2005). At the same time, the United States has agreed to join the open-ended dialogue after explicitly stating not to agree on Kyoto Protocol's GHG emissions reduction limits (Dawn 2005).

The United States has signed the Asia-Pacific Partnership on Clean Development and Climate, a pact that allows partnering countries to set their goals for reducing GHG emissions individually, but with no enforcement mechanism. The Asia-Pacific Partnership on Clean Development and Climate, also known as AP6, is an international non-treaty agreement among Australia, Canada, India, Japan, the People's Republic of China, South 
Korea, and the United States. The Asia-Pacific Partnership on Clean Development and Climate was announced at an Association of South East Asian Nations (ASEAN) regional forum, and launched on January 12, 2006 at the partnership's inaugural ministerial meeting in Sydney (BBC News 2005). The United States is also a signatory to the Sydney Declaration to the Climate Change, Energy Security, and Clean Development which was agreed by Asia Pacific Economic Forum (APEC) members on September 8, 2007. The Sydney Declaration has stated a goal of decreasing energy intensity by 2030 from the 2005 level and increase forest cover in APEC member countries by 20 million hectares by 2020 (SMH 2007). The Sydney Declaration felt short of mandating reduction of GHG emissions but it is a step in the right direction.

The United States' position vis-à-vis GHG emissions reduction is to cut down GHG emissions without agreeing to mandates or firm targets. The United States' position can be better understood by analyzing key economic statistics and GHG emissions data (using 1990 as base year) presented in Table 1. The year 1990 was also selected as a baseline year for the Kyoto Protocol emissions reductions, and the data in Table 1 is available for 1990-2006. During 1990 and 2006, GHG emissions in the United States have increased at an average annual rate of 0.9 percent, with total increase of 15 percent. During the same period, gross domestic product (GDP) grew at an annual rate of 3.0 percent, electricity consumption grew at an annual rate of 1.9 percent, and population grew at an annual rate of 1.1 percent. On a positive side, the GHG emissions rate of growth is slightly slower than that for total energy or fossil fuel consumption, and much slower than that for electricity consumption, population increase or overall GDP growth. The data presented in Table 1 suggests that the U.S. corporations and public sector are aware of the environmental problems and are employing emissions reduction methodologies without any mandatory targets. Also, the slow growth of the GHG emissions can be attributed to the growth of the voluntary carbon credits market in the United States.

Table 1

Trends in U.S. Energy Data (Index 1990 = 100)

\begin{tabular}{|l|c|c|c|c|c|c|c|c|c|c|}
\hline \multicolumn{1}{|c|}{ Year } & $\mathbf{1 9 9 0}$ & $\mathbf{1 9 9 5}$ & $\mathbf{2 0 0 0}$ & $\mathbf{2 0 0 1}$ & $\mathbf{2 0 0 2}$ & $\mathbf{2 0 0 3}$ & $\mathbf{2 0 0 4}$ & $\mathbf{2 0 0 5}$ & $\mathbf{2 0 0 6}$ & $\begin{array}{c}\text { Ave. } \\
\text { Annual } \\
\text { Growth } \\
\text { Rate }\end{array}$ \\
\hline Key Variables & 100 & 113 & 138 & 139 & 141 & 145 & 150 & 155 & 159 & $3.0 \%$ \\
\hline Population & 100 & 106 & 114 & 113 & 114 & 116 & 117 & 118 & 119 & $1.1 \%$ \\
\hline $\begin{array}{l}\text { Electricity } \\
\text { Consumption* }\end{array}$ & 100 & 112 & 127 & 125 & 128 & 129 & 131 & 134 & 135 & $1.9 \%$ \\
\hline $\begin{array}{l}\text { Fossil Fuel } \\
\text { Consumption* }\end{array}$ & 100 & 107 & 117 & 115 & 116 & 116 & 119 & 119 & 117 & $1.0 \%$ \\
\hline $\begin{array}{l}\text { Energy } \\
\text { Consumption* }\end{array}$ & 100 & 108 & 116 & 112 & 115 & 115 & 118 & 118 & 117 & $1.0 \%$ \\
\hline GHG Emissions** & 100 & 106 & 114 & 113 & 114 & 114 & 115 & 116 & 115 & $0.9 \%$ \\
\hline
\end{tabular}

*Energy constant weighted value.

** Global Warming Potential (GWP) - Weighted values

Source: EPA 2008

Table 2 summarizes the change in GHG emissions data for the major polluting countries that are not subject to the Kyoto mandatory cuts. The time period selected is 1990-2004. The authentic data for 2005 and 2006 were not available for every selected country. The United State GHG emissions have increased by 16 percent. Russian GHG emissions have decreased by 32 percent. The alarming statistics are coming out of China and India. India's GHG emissions have increased by 55 percent with no sign of reversing the trend. China, the second largest GHG emitter after the United States, has not taken appropriate measures to cut down their emissions, and emissions have increased by 47 percent during the same period.

In 2004 the total Chinese GHG emissions were about 54 percent of the total U.S. GHG emissions. China has been building an average of one coal-fired power plant every week, and plans to continue doing so for years (Brahic 2007). Various predictions see China overtaking the United States in total GHG emissions sometimes between 2008 and 2010. The Chinese government insists that the GHG emissions level of any given country is a 
multiplication of its per capita emission and its population. The Chinese and Indian GHG emissions statistics somewhat validate the United States position not to join Kyoto Protocol, which has not targeted on the emerging economies' GHG emissions.

Table 2

GHG Emissions Data for Polluting Nations Not Subject to Kyoto Reductions

\begin{tabular}{|c|c|}
\hline Country & GHG Emissions Change (1990-2004) \\
\hline U.S. & $+16 \%$ \\
\hline Russia & $-32 \%$ \\
\hline China & $+47 \%$ \\
\hline India & $+55 \%$ \\
\hline
\end{tabular}

Source: Energy Information Administration 2008

The United States did adopt a conciliatory position at the Bali conference in December 2007 and agreed to numerical targets. It is widely believed that the United States will become a major player in the carbon market because both presidential candidates, Barack Obama and John McCain have supported a carbon cap-and-trade system in the United States. A number of legislative initiatives were discussed in 2008 and the discussion is expected to be continued in 2009. A recent study by the United States Environmental Protection Agency (EPA) concluded that a balanced carbon cap-and-trade program (details are found in Module 8) will not hurt the United States economy as feared by many policy makers (Power 2008). It is ultimately the decision of the new United States president and legislatures in early 2009 to redefine the home and global GHG emissions market (Murray 2008).

\section{THE WORLD BANK GROUP}

The World Bank Group has been a proactive player in the carbon finance market. One of the organizational units exclusively involved in carbon projects is the World Bank Carbon Finance Unit (CFU). Another initiative by the World Bank is to set up the Strategic Framework on Climate Change and Development (SFCCD) which is a partnership among member countries to tackle global environmental problems (Carbon Finance Unit 2008). In 2002, only the World Bank and the Dutch government were involved in carbon purchasing programs, but as a result of the World Bank's leadership, there are close to one hundred public and private carbon funds in the market (The World Bank 2008).

\section{The Carbon Finance Unit}

The Carbon Finance Unit (CFU) is funded by contributions by global corporations and governments who are members of the Organization for Economic Cooperation and Development (OECD). Funds are used for the purpose of purchasing project-based greenhouse gas (GHG) emissions reductions in developing countries (CDM projects) and economies in transition (JI projects). The emissions reductions are purchased through one of the CFU's carbon funds on behalf of the contributor, for CDM projects or for Joint JI projects. The list of the CFU's carbon funds and facilities is presented in the Table 3.

Unlike other World Bank development finance units, theses carbon funds and facilities do not lend funds to carbon projects. Rather, they offer contracts to purchase verified $\mathrm{CO} 2 \mathrm{e}$ emissions reductions in a commercial transaction, paying for them annually or periodically. The purchase of carbon credits by these funds and facilities, as a result of emissions reductions, add an additional revenue stream in hard currency and improve bankability of these projects. This reliable revenue stream improves project's cash flow, and reduces the risks for commercial lenders. Thus, carbon finance provides a means of leveraging new private and public investments into projects that reduce GHG emissions, thereby mitigating climate change while contributing to sustainable development. Without the additional revenue generated by carbon credits, these projects might not be possible.

Another contribution of the World Bank's Carbon Finance Unit (CFU) is to strengthen and streamline the Kyoto Protocol mechanism. The Policy and Methodology Team in the CFU systematically observes the CDM 
regulatory process and contributes to rulemaking for the CDM by interpreting regulatory decisions, providing input, and developing new methodologies. Through these actions, the Policy and Methodology Team bridges the gap between general guidelines and practical methodologies for carbon projects. The CFU also prepares policy and position papers and takes an active role in initiating research and studies on methodological and policy issues related to the CDM. Almost all the CFU publications are available to global corporations and investors (The World Bank 2008).

Table 3

World Bank Carbon Funds \& Facilities

\begin{tabular}{|c|c|c|}
\hline & Name of Fund / Facility & Key Features \\
\hline 1 & Prototype Carbon Fund & $\begin{array}{l}\text { Operating since April } 2000 \text {, this is the first carbon fund. This fund is a } \\
\text { partnership between seventeen corporations and six governments. The fund's } \\
\text { total capital is about } \$ 180 \text { million. }\end{array}$ \\
\hline 2 & BioCarbon Fund & $\begin{array}{l}\text { The BioCarbon Fund is a public and private partnership promoting bio-diversity } \\
\text { and conservation. The fund purchase carbon credits from land use and forestry } \\
\text { projects. }\end{array}$ \\
\hline 3 & $\begin{array}{l}\text { Community Development Carbon } \\
\text { Fund }\end{array}$ & $\begin{array}{l}\text { This fund started in March } 2003 \text { with the objective of uplifting poor developing } \\
\text { countries and reducing their carbon emissions. The fund operates with the } \\
\text { assistance of public and private sectors. }\end{array}$ \\
\hline 4 & Italian Carbon Fund & $\begin{array}{l}\text { This fund started in fall 2003. The fund purchases carbon credits from } \\
\text { developing countries for Italian public and private sectors. }\end{array}$ \\
\hline 5 & The Netherlands CDM Facility & $\begin{array}{l}\text { This facility was established through a cooperation of the Netherlands and the } \\
\text { World Bank with the sole purpose of purchasing carbon credits from CDM } \\
\text { projects in developing countries. }\end{array}$ \\
\hline 6 & $\begin{array}{l}\text { The Netherlands European Carbon } \\
\text { Facility }\end{array}$ & $\begin{array}{l}\text { This agreement between the Netherlands and the International Finance } \\
\text { Corporation (IFC) was signed in August 2004. The fund purchases carbon } \\
\text { credits, on the behalf of the government, only from JI projects located in } \\
\text { economies in transition. }\end{array}$ \\
\hline 7 & Danish Carbon Fund & $\begin{array}{l}\text { The Danish Carbon Fund is an example of a public and private sector } \\
\text { cooperation to assist Danish businesses. The fund was set up in January } 2005 \text {. }\end{array}$ \\
\hline 8 & Spanish Carbon Fund & $\begin{array}{l}\text { This fund invests in JI and CDM projects and promotes cleaner technologies } \\
\text { and sustainable development. The fund was set up in } 2004 \text { with the cooperation } \\
\text { of the Spanish government and the World Bank. }\end{array}$ \\
\hline 9 & Umbrella Carbon Facility & $\begin{array}{l}\text { This is an aggregating facility to pool funds from the International Bank for } \\
\text { Reconstruction \& Development (IBRD) managed carbon funds. The facility } \\
\text { invests in large projects because the total funds available are } \$ 719 \text { million. }\end{array}$ \\
\hline 10 & Carbon Fund for Europe & $\begin{array}{l}\text { This is a trust fund established by the World Bank, in cooperation with the } \\
\text { European Investment Bank (EIB). Both prestigious institutions bring their } \\
\text { expertise to purchase carbon credits from CDM or JI projects. }\end{array}$ \\
\hline 11 & Forest Carbon Partnership Facility & $\begin{array}{l}\text { This facility devises policies and offers economic assistance in activities that } \\
\text { would reduce emissions from deforestation and degradation. As of } 2008 \text {, about } \\
\text { forty countries had expressed an interest in participating. }\end{array}$ \\
\hline
\end{tabular}

Source: Carbon Finance Unit 2008

\section{The World Bank Plan for Forests}

The World Bank has established a number of funds and programs primarily to assist medium and low income countries in their GHG reduction efforts and save their forests. The Forest Carbon Partnership Facility (FCPF) and the BioCarbon Fund are the two major initiatives of the World Bank. The financing model of these two funds also highlights importance of public and private sectors cooperation in saving the forests and reducing GHG emissions (Jacquot 2008).

Table 4 lists the GHG emissions of various economic sectors in the member countries of the World Bank Group (International Bank for Reconstruction and Development and the International Development Association). Land-use change and forestry account for 32 percent of GHG emissions. The World Bank Group realizes the 
importance of land-use and forestry sector in their efforts to manage GHG emissions. Electricity and heat generation contribute another 20 percent of emissions. Agriculture and transportation are the third and fourth major contributors of GHG emissions.

Table 4

GHG Emissions by Sectors

(IBRD and IDA members)

\begin{tabular}{|c|c|}
\hline Economic Sectors & Percentage of Total Emissions \\
\hline Land-use change and forestry & $32 \%$ \\
\hline Electricity \& Heat & $20 \%$ \\
\hline Agriculture & $15 \%$ \\
\hline Industry & $11 \%$ \\
\hline Other sectors & $11 \%$ \\
\hline Transportation & $6 \%$ \\
\hline Waste & $3 \%$ \\
\hline
\end{tabular}

Source: www.worldbank.org

\section{The Carbon Partnership Facility}

The Carbon Partnership Facility (CPF) was set up in 2008 by the World Bank with an initial funding of $\$ 500$ million. The main objective of the CPF is to provide financial assistance to carbon reduction projects. The CPF will purchase carbon credits to be generated beyond 2012, unlike other funds/facilities which have a short-term assistance horizon. The facility promotes long-term and somewhat risky investment programs for sustainable development. Some of the targeted sectors are renewable energy, fuel substitution in power generation and industry, waste management systems, carbon capture and storage, and a myriad of energy-efficient industrial systems.

\section{The Clean Energy Investment Framework}

The objective of the Clean Energy Investment Framework (CEIF) is to facilitate development of lowcarbon emitting energy sources. It is believed that increased energy sources are crucial for economic development, and that a country can develop new sources of energy while reducing their carbon emissions. There are multiple programs available to countries, including loans, grants, and finance guarantees for clean energy sector.

\section{Climate Investment Funds}

Another initiative of the World Bank Group includes the Climate Investment Funds (CIFs), which were approved by the World Bank as in early 2008. CIFs were set up to promote international cooperation on climate change and to support the Bali Action Plan of December 2007. The CIFs are an important new source of interim funding through which the Multilateral Development Banks (MDBs) will provide additional grants and concessional financing to developing countries to address urgent climate-related challenges. The CIFs will enable a dynamic partnership between the MDBs and developing countries to undertake investments that achieve a country's development goals while choosing a low carbon development path (The World Bank 2008).

The two major climate funds are the Clean Technology Fund and the Strategic Carbon Fund. The Clean Technology Fund will complement existing green financing mechanisms. The Clean Technology Fund is available for private and public sectors in their efforts to mitigate GHG emissions and transform participating economies into low-carbon economies. There are wide arrays of financial instruments available including grants, subsidized loans, bridge financing, and loan guarantees. The Strategic Climate Fund promotes programs that have potential to bring lasting impacts on multiple sectors within a country. The fund also targets sustainable forestry and agriculture projects and shares knowledge among the MDBs on climate change. 


\section{THE WORLD RESOURCE INSTITUTE}

The World Resource Institute (WRI) is an environmental think tank involved in research and analysis of global sustainability issues and making policy recommendations. The WRI head office is located in Washington, D.C. The WRI was set up in June 1982, and it is one of the earliest organizations targeting global environmental problems. The WRI publishes numerous reports and case studies to guide profit and not-for-profit entities to manage their carbon emissions. WRI studies have also focused on the forestry industry as one of the solutions to global environmental problems. The WRI mission statement focuses on educating citizens and corporations on ways to protect the environment, offering suggestions about market based solutions to tackle global environmental problems, helping industries to set up standards, and preserving forests (WRI 2008).

One of the significant accomplishments of the WRI is development of the Carbon Value Analysis Tool (CVAT). CVAT is a screening tool used to help corporations integrate the benefits of GHG emissions reductions into energy-related investment decisions. The corporations and their investors can test the sensitivity of an energy related project's internal rate of return (IRR) to the quantity of GHG emissions reductions. The corporation or the investors can establish a relationship between GHG emissions reductions and profitability of the project. CVAT integrates this value into traditional financial analysis by assigning a market price, either actual or projected, to carbon emissions reductions. The World Resource Institute screening tool (CVAT) estimates reductions of direct and indirect emissions using standards developed by the GHG Protocol Initiative (WRI 2008).

\section{THE INSTITUTIONAL INVESTOR'S GROUP ON CLIMATE CHANGE}

The Institutional Investor's Group on Climate Change (IIGCC) was formed by 11 institutional investors in 2001, and it currently targets three key industries: power generation, aviation, and construction. As of June 2008, IIGCC was made up of about fifty major European institutional investors and pension funds that emphasize environmental issues in their long term investment decisions. The objective of the IIGCC is to encourage corporations to disclose their carbon emissions and adopt socially responsible GHG emission strategies as prerequisites of future financing (IIGCC 2008).

According to the official website of the group, the purpose of the IIGCC is to promote a better understanding of the implications of climate change amongst group members and other institutional investors. Furthermore, the IIGCC encourages corporations and markets that they invest in to address any material risks or opportunities to their businesses associated with climate change or a shift to a lower carbon economy. This is one of the earliest, and perhaps the first, organized efforts by institutional investors to spotlight carbon issues as an investment variable.

\section{THE CARBON DISCLOSURE PROJECT}

The Carbon Disclosure Project (CDP) was set up in December 2000 by 35 institutional investors. The CDP is an impartial not-for-profit entity with the objective of creating "a lasting relationship between shareholders and corporations regarding the implications for shareholder value and commercial operations presented by climate change" (CDP 2008). The purpose of the project was to make inquiries and to encourage large global corporations to adopt environment-friendly measures in their business operations. These institutional investors were concerned about unexpected future risks as a result of investing is polluting industries and exposing themselves to new regulations, which might negatively influence profitability. In 2002, these 35 institutional investors managing $\$ 4.5$ trillion asked the largest global 500 corporations to disclose their susceptibility to climate risk. This initiative was called the first Carbon Disclosure Project. Overall findings were not very encouraging because corporations were not paying attention to carbon exposure and because the response rate was also lower than expected. A major achievement was the third Carbon Disclosure Project, which was launched in 2005 and included 143 institutional investors managing \$21 trillion. The number of concerned institutional investors increased by more than four-fold in three years, and corporations could no longer ignore the questionnaire sent by the CDP. The response rate to the questionnaire improved from 78 percent in 2002 to 89 percent in 2005; at the same time, the fully-completed questionnaire response rate increased from 47 percent to 71 percent (CDP 2008). 
In early 2006, the group made their fourth request to 1,933 of the world's largest publicly traded corporations to disclose their investments in GHG reduction projects (CDP 2008). The 2006 list included Fortune 500 corporations, 258 of the world's largest electric utilities, 300 of the largest GHG emitters in Canada, 200 of the largest corporations in Germany, 150 of largest corporations in Japan, 150 of the largest corporations in Australia and New Zealand, 120 of the largest corporations in France, 100 of the largest corporations in the UK, 50 of the largest corporations in Brazil, and 40 of the largest corporations in Asia outside of Japan. All the 1,933 corporations were requested to complete the questionnaire within four months.

In 2008, the total asset value of the CDP-related institutional investors increased to $\$ 57$ trillion (a thirteenfold increase since 2002). The sixth Carbon Disclosure Project was launched in 2008 and targeted about 3,250 large corporations from the United States, Europe, Latin America, Australia, South Africa, and Asia, including China. This was the most comprehensive study of large global corporations' attitudes and policies towards GHG emissions issues. The questionnaire included queries under the following categories: risk and opportunities, GHG emissions accounting, additional GHG emissions accounting, corporate performance, and corporate governance. The results of the project are available to public. The list of the corporations and groups surveyed for the sixth CDP project (May 2008) is found in Table 5.

Table 5

Corporations Surveyed for the Sixth CDP Project

\begin{tabular}{|l|l|c|c|}
\hline \multicolumn{1}{|c|}{ Origin of Corporations } & $\begin{array}{c}\text { Number of Largest } \\
\text { Corporations* }\end{array}$ & Affiliation of Corporations \\
\hline 1 & Global Corporations & 500 & Financial Times 500 \\
\hline 2 & The United States & 500 & S\&P 500 \\
\hline 3 & The United Kingdom & 350 & ASX 200 \\
\hline 4 & Australia & 200 & \\
\hline 5 & Canada & 200 & \\
\hline 6 & Germany & 200 & Nutek, Folksam, KLP \\
\hline 7 & India & 200 & SBF 120 \\
\hline 8 & Nordic Countries & 193 & FTSE/JSE 100 \\
\hline 9 & Japan & 150 & \\
\hline 10 & France & 120 & Sao Paolo Exchange \\
\hline 11 & China & 100 & \\
\hline 12 & South Africa & 100 & 100 \\
\hline 13 & Switzerland & 100 & \\
\hline 14 & Global Transport & 75 & \\
\hline 15 & Brazil & 50 & NZX 50 \\
\hline 16 & Asia excluding China, Japan, and South Korea & 50 & S\&P Latin America \\
\hline 17 & South Korea & 50 & IBEX 35 \\
\hline 18 & Netherlands & 50 & \\
\hline 19 & New Zealand & 40 & \\
\hline 20 & Italy & 40 & 35 \\
\hline 21 & Latin America & & \\
\hline 22 & Spain & & \\
\hline
\end{tabular}

* Large corporations based on market capitalization

\section{REFERENCES}

1. Brahic, Catherine. 2007. China's Emissions May Surpass the U.S. in 2007. New Scientists, April 2007, http://environment.newscientist.com/article/dn11707-chinas-emissions-to-surpass-the-us-withinmonths.html, August 20, 2008.

2. CDP. 2008. Carbon Disclosure Project, www.cdproject.net

3. $\quad$ Carbon Finance Unit. 2008. www.carbonfinance.org, August 17, 2008.

4. Dawn. 2008. UAE Starts Work on Zero-Carbon City. Dawn. February 11, 2008.

5. Eilperin, Juliet. 2005. Climate Plan Splits U.S. and Europe. Washington Post, July 2, 2005. 
6. $\quad$ EPA. 2005. Environment Protection Agency.

http://www.epa.gov/climatechange/emissions/downloads/08_CR.pdf

7. IIGCC. 2008. Institutional Investor's Group on Climate Change, (www.iigcc.org), August 29, 2008.

8. Jacquot, Jeremy E. 2008. World Banks Plan Aims to Reduce Deforestation and Forest Degradation. Treehugger, http://www.treehugger.com/files/2007/12/world_bank_plan.php, October 6, 2008.

9. Murray, Alan. 2008. Next President Needs to Uncap Debate on Cost of Emissions Curbs. The Wall Street Journal, March 17, 2008. p. A2.

10. Power, Stephen. 2008. EPA Says Carbon Caps Won't Harm Economy Much. The Wall Street Journal, March 17, 2008, p. A2.

11. SMH. 2008. Sydney Declaration on Climate Change and Energy. The Sydney Morning Herald, September 9, 2007, http://www.smh.com.au/news/

12. The World Bank. 2008. The World Bank Group. www.worldbank.org/climateconsult), August 17, 2008.

13. WRI. 2008. World Resource Institute. www.wri.org, September 17, 2008.

14. WSJ. 2005. Global Warming: a Cloudy Outlook. The Wall Street Journal, December 10, 2005.

\section{$\underline{\text { NOTES }}$}

